INSIGHTS INTO REGIONAL DEVELOPMENT

ISSN 2669-0195 (online) http://jssidoi.org/IRD/ 2020 Volume 2 Number 3 (September) http://doi.org/10.9770/IRD.2020.2.3(1)

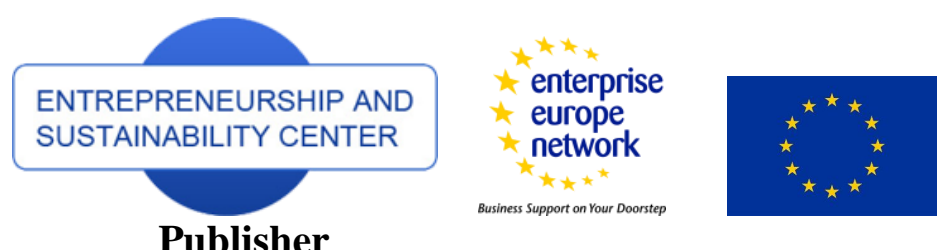

http://jssidoi.org/esc/home

\title{
DOUBLE-ENTRY BOOKKEEPING AND BALANCE OF PAYMENTS: THE NEED FOR DEVELOPING A NEW APPROACH*
}

\author{
Edoardo Beretta ${ }^{1}$, Alvaro Cencini ${ }^{2}$ \\ ${ }^{1,2}$ Università Della Svizzera Italiana (USI), Via Giuseppe Buffi 13, Lugano, Switzerland \\ E-mails: ${ }^{1}$ edoardo.beretta@usi.ch; ${ }^{2}$ alvaro.cencini@usi.ch
}

Received 20 March 2020; accepted 25 April 2020; published 30 September 2020

\begin{abstract}
On the basis of the identity between each country's global imports (commercial and financial) and exports (commercial and financial), which is one of the fundamental economic principles of the balance of payments, the paper highlights why and how the leading account of transactions from/to the rest of the world needs to be reformed. As a strategic goal, the balance of payments should finally move beyond its current purely statistical and simple-entry bookkeeping approach in order to improve its macroeconomic relevance. This would also imply a new way of carrying out cross-border payments, which could in turn pave the way for a new system of international payments. The development of an economic account of the nation as a whole and the introduction of a consistent way of recording transactions following a truly double-entry bookkeeping would also erase statistical discrepancies ex ante and reflect the necessary equality (identity) of credits and debits both for all transactions taken together and for each of them separately. The balance of payments is already a powerful economic tool, but only through a money-consistent reform would it display its full potential.
\end{abstract}

Keywords: balance of payments; double-entry bookkeeping; nation's economic account; reserve assets

Reference to this paper should be made as follows: Beretta, E., Cencini, A. 2020. Double-entry bookkeeping and balance of payments: the need for developing a new approach. Insights into Regional Development, 2(3), 610-629. https://doi.org/10.9770/IRD.2020.2.3(1)

JEL Classifications: B27, F32, F33, P33

\footnotetext{
* This research was partly supported by the project,which has received funding from the European Union's Horizon 2020 research and innovation programme European Research Council (ERC) under the European Union's Horizon 2020 research and innovation programme Marie Sklodowska-Curie Research and Innovation Staff Exchanges ES H2020-MSCA-RISE-2014 CLUSDEVMED (2015-2019) Grant Agreement Number 645730730
}
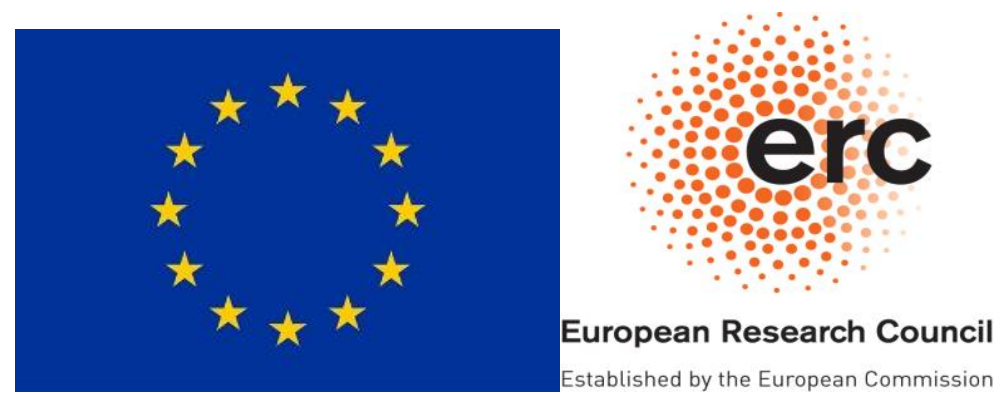


\section{INSIGHTS INTO REGIONAL DEVELOPMENT}

ISSN 2669-0195 (online) http://jssidoi.org/IRD/

2020 Volume 2 Number 3 (September)

http://doi.org/10.9770/IRD.2020.2.3(1)

\section{Introduction}

We can preliminarily (and safely) state that the balance of payments, namely "a statistical statement that systematically summarizes, for a specific time period, the economic transactions of an economy with the rest of the world" (International Monetary Fund, 1997), is the most relevant external statistical document registering all international (traceable) commercial and financial transactions between countries. It is common knowledge that this statistical tool can be separated into a "current account" and a "capital and financial account". "Reserve assets", which are a subcategory of the capital and financial account, mainly keep track of variations in official reserves made up of foreign currencies, precious metals and SDRs. Equally, there cannot be any uncertainties with specific regard to the double-entry bookkeeping principles ruling the balance of payments, namely that "every recorded transaction is represented by two entries with equal values. One entry of these pairs is designated a credit with a positive arithmetic sign, the other is designated a debit with a negative sign" (International Monetary Fund, 1997). So far, nothing new or original. And this is precisely the risk with today's view of the balance of payments, that it may be interpreted (wrongly) as a mere tautological statement. Far more interesting, however, because they are largely neglected:

1. the double-entry bookkeeping logic behind the balance of payments as conceived today (positive analysis);

2. the double-entry bookkeeping logic behind the balance of payments as it should be conceived in future (normative analysis) to formulate a statistically-relevant statement coherent with the essence of modern money and a true system of international payments.

We begin by analyzing point 1 ,, which refers to the current notion of balance of payments: its equilibrium results from "real" flows (cf. current account) matching "financial" flows (cf. capital and financial account). Under these conditions "[t]he balance of payments must accordingly be looked at as a whole rather than in terms of its individual parts" (Stern, 1973). However, a similar approach appears to be somewhat reductive since a situation of equilibrium between two distinct transactions reflects a simple-entry rather than double-entry bookkeeping logic. In fact, it would be simplistic - therefore, wrong - to claim that our purchase is our foreign correspondent's sale (which is a truism), when the logic of double-entry bookkeeping requires both his and our purchases to be matched by simultaneous and equivalent sales. Hence, a second approach (cf. point 2.) should be explored, namely one reflecting a truly double-entry bookkeeping approach. More precisely, the paper will:

- show that every net buyer (seller) on the commercial market (cf. goods/services) must be a net seller (buyer) on the financial market (cf. securities);

- re-imagine the role of the "reserve assets" item and, more generally, of international reserves in the balance of payments itself.

The article will, first, deal with the identity between each country's global imports, commercial and financial, (IM) and its global exports, commercial and financial, (EX), which are explained in Part 1. In Part 2, we will highlight the way in which the current account and capital and financial account are involved in the external transactions of a country. Part 3 will clarify why the reserve account (including the so-called "reserve assets") is the account of a country taken as a whole, while Part 4 will explain why today's system of international payments fails to recognize the existence of countries as sets of their residents. The methodological approach adopted will be mainly logical-analytical, supported by insights from statistical and numerical evidence. 
INSIGHTS INTO REGIONAL DEVELOPMENT

ISSN 2669-0195 (online) http://jssidoi.org/IRD/

2020 Volume 2 Number 3 (September)

http://doi.org/10.9770/IRD.2020.2.3(1)

\section{The identity between each country's global imports (IM) and its global exports (EX)}

The starting point of the entire discussion is that "countries' international transactions have to comply with the balance of payments identity IM $\equiv$ EX, where IM stands for the totality of a country's imports, financial and commercial, and EX represents the totality of its exports, both commercial and financial, and [...] this is so even when their overall imports exceed their overall exports [or vice versa]" (Cencini, 2017). In other words, even where a current account surplus (deficit) clearly represents a positive (negative) disequilibrium of the transactions recorded therein over those registered in the capital and financial account, the balance of payments itself is perfectly balanced. This means that all the operations in all the accounts taken together are necessarily equal to zero. "As with any other account, the total receipts of a country are bound be equal to the total payments of that country, if one includes all the receipts and all the payments of the country in the account" (Meade, 1970).

Bearing in mind that "gold" is no longer used to settle international transactions and that the "purchasing power" used to cover a commercial imports surplus derives from corresponding excess financial exports (current account deficits are financed by an equivalent sale of financial claims as registered in the capital and financial account), total receipts (+) are necessarily equal to total payments (-). Or, as formulated by Krugman and Obstfeld (1997), "this principle of payments accounting holds true because every transaction has two sides: if you buy something from a foreigner you must pay him in some way, and the foreigner must then somehow spend or store your payment". This axiom could be translated as follows: if subject A in country A buys (sells) - either goods and services (cf. current account) or financial claims (cf. capital and financial account) - from (to) subject B in country B, he will necessarily have to sell (buy) goods, services or financial claims to finance his purchases. In other words, "[l] ooked at more closely [...] Krugman and Obstfeld's quote discloses the presence of a fundamental law guaranteeing the necessary duality between each resident's sales and purchases. In fact, if the foreigner from whom a resident buys must spend his payments - if he stores it, he spends it for the purchase of claims on bank deposits -, this means that the purchase of a resident is necessarily matched by an equivalent sale and that, reciprocally, the sale of the foreign correspondent is balanced by a purchase of the same amount" (Citraro, 2004).

Both individuals are, inevitably, commercial and/or financial buyers and purchasers at the same time and within every transaction. As we shall see,because of the flow nature of money, the law of the necessary equality of sales and purchases applies also when transactions concern countries considered as sets of their residents. Although bank money continues to be misinterpreted as an asset or a commodity, it is a fact that ("[money is] a circular flow that does not survive the payment occurring during a transaction between two economic agents in a capitalist economy [...]. [T] he instantaneous reflux of money to its point of origin cannot be identified with an equilibrium condition that might be satisfied (or not). It is, in fact, a fundamental law of bank money that will always be logically true, regardless of the behavior of economic agents" (Pilkington, 2007)). But let us for a moment suppose that money is in fact an asset: if so, (inter)national exchanges would split up into two non-simultaneous transactions. Goods/services/financial claims of resident A in country A against a sum of money of resident B in country B would mean a sale for the former and a purchase for the latter. At the same time, as described by Cencini (2005), "[m]oney being also considered as a simple veil, the seller will later become a purchaser, yet sale and purchase will be equivalent only at equilibrium (which is but one possible outcome of economic agents' behaviour), and they will remain two chronologically distinct events". In reality, issued by banks as a spontaneous acknowledgement of debt of zero intrinsic value, money is a vehicular means by which payments are carried out and not the object of these payments. By its own nature, money is a flow and not a stock. So, payments that are conveyed by money must have a real stock of produced goods and services as their real content. As monetary payments obey the principle of double-entry bookkeeping; each agent entering an exchange is simultaneously credited and debited by the same amount of money, whose circular flow is instantaneous. Money is present in each payment and flows immediately back to its point of injection as soon as the payment is completed. Finally, the terms of any exchange are real goods, present and future, conveyed through the circular flow of money. Being 


\section{INSIGHTS INTO REGIONAL DEVELOPMENT}

ISSN 2669-0195 (online) http://jssidoi.org/IRD/

2020 Volume 2 Number 3 (September)

http://doi.org/10.9770/IRD.2020.2.3(1)

at the same time credited (debited) and debited (credited) for the same amount of money, economic agents are therefore, simultaneously, sellers (buyers) and buyers (sellers) of real goods (either in the form of produced goods and services or in that of financial claims).

The formulations above describe the so-called "law of the identity between each agent's sales and purchases" formulated by Bernard Schmitt (1975). In fact, based on the circular essence of bank money, every net buyer (seller) on the commercial market (cf. goods/services) must be a net seller (buyer) on the financial market (cf. securities). Put another way, an economic subject has to finance his purchases by a concurrent sale and - each time he sells - he must concurrently purchase. If this holds true for the individual agent, it is equally possible to treat the country itself (the set of its residents) as "a single macroeconomic agent acting on the commodity and financial markets. Hence, in the same way as any single resident can finance his purchases only through equivalent sales, a country can finance its commercial and financial imports only through equivalent sales of goods, services, and financial assets" (Cencini, 2005). This is confirmed by the IMF Balance of payments manual, which states that "[m]ost entries in the balance of payments refer to transactions in which economic values are provided or received in exchange for other economic values. These values consist of real resources (goods, services, and income) and financial items. Therefore, the offsetting credit and debit entries called for by the recording system are often the result of equal amounts having been entered for the two items exchanged" (International Monetary Fund, 1993). The terms "goods, services, and income" refer to the current account, while "financial items" refer to the capital and financial account.

Let us take the example of the payment of a reserve currency country's net imports (the case of the United States of America). The American nation would pay for its net purchases of goods and services by transferring a certain amount of its domestic currency $(\$ 100)$ to its foreign creditors in the rest of the world. Apparently, U.S. net commercial purchases are not matched by any sale. However, this conclusion cannot be right since it openly contravenes the fundamental reciprocity implied by double-entry bookkeeping. At the same time, since money is a circular flow, there cannot be any net transfer of US Dollars to the rest of the world. This means that the payment by the American banking system does not prevent - why should or how could it? - the immediate reflux of US Dollars to their point of departure. But, once again, is this not another way of saying that US net commercial purchases remain unmatched by equivalent sales? It is not. In fact, if on the one hand money units (\$100) are immediately recovered by the American banking system, on the other hand the rest of the world obtains, through the circular flow of US Dollars, a financial asset (a claim on US bank deposits) while the American nation obtains an equivalent amount of domestic output of the rest of the world. This example may be expressed in numerical terms (Table 1). On the one hand, US importers pay for their outstanding commercial transactions (\$100). On the other hand, exporters from the rest of the world (RW) receive the countervalue in domestic money ( $\mathrm{x}$ units of MRW) on their bank accounts. This is precisely the way any transaction is settled from an individual perspective. Thus, the debtor pays and gets rids of his liability by means of his domestic currency $(\$ 100)$ - regardless of whether the country is a reserve currency or a non-reserve currency one - while the creditor is paid in his own domestic currency ( $\mathrm{x}$ units of MRW).

The U.S. Central Bank takes over the payment of its local importers and transfers it to the banking system of the rest of the world. The Central Bank's monetary intermediation makes it possible for US importers to pay in their local currency $(\$ 100)$ - of course, in the American case this is also helped by the privileged status of the US Dollar ("the United States has the privilege of being able to pay its debts in an international means of payment which it can print itself, and which is accepted by the international banking system" (Teunissen, 1987)), yet the payment process would work in the same way for any other payer in the rest of the world - while the payee gets the countervalue in his local currency. What happens in between is the "monetization of an external gain" by the banking system (represented by its central bank) of the rest of the world, RW, which stores the US Dollar amount in its foreign currency reserves while it creates the countervalue in local money units to the benefit of RW's exporters. 
INSIGHTS INTO REGIONAL DEVELOPMENT

ISSN 2669-0195 (online) http://jssidoi.org/IRD/

2020 Volume 2 Number 3 (September)

http://doi.org/10.9770/IRD.2020.2.3(1)

Table 1. Payment of a reserve-currency country's net imports

US banking system (with net commercial deficit)

\begin{tabular}{|c|c|c|c|}
\hline \multicolumn{3}{|c|}{ Liabilities } & Assets \\
\hline Banking syst & m of RW & US importers & \\
\hline \multicolumn{4}{|c|}{ Banking system of RW (with net commercial surplus) } \\
\hline Liabilities & & & Assets \\
\hline Exporters of RW & $x$ units of $M R W$ & US banking system & $\$ 100$ \\
\hline
\end{tabular}

Therefore, US importers pay $\$ 100$ while exporters from the rest of the world (RW) receive $\mathrm{x}$ units of MRW. The transaction is settled from a microeconomic perspective. Let us now look at what happens on a macroeconomic level, namely between countries as sets of residents. The US banking system enters the payment in the banking system of the rest of the world (RW) under its liabilities (\$100) whereas the banking system of the rest of the world (RW) enters the payment received under its assets (\$100). Even though the US can pay for its net imports in US Dollars, their payment obeys the same rule applying to any other country. Indeed, the flow nature of money and the compliance with double-entry bookkeeping are such that the Dollars paid to RW flow immediately back to the US banking system. Net purchases of commercial goods from R, the USA is therefore, at the same time and for the same value, a net seller of financial claims on US bank deposits. Hence, each country's purchases, commercial and financial, are funded by equivalent and simultaneous sales.

- US economy:

o net purchase of goods/services from RW (-\$100);

$\circ$ net sale of a claim on domestic income, namely national bank deposits $(+\$ 100)$;

- Rest of the world's (RW's) economy:

$\circ$ net purchase of a claim on US income, namely national US bank deposits (-\$100);

○ net external sale of goods/services $(+\$ 100)$.

If mainstream economics remarks that "[a]lthough the balance of payments accounts are, in principle, balanced, imbalances result in practice from imperfections in source data and compilation" (International Monetary Fund, 2009) and the aggregate sum of debts and credits has to be specifically offset by an item called "net errors and omissions", it is because it is de facto neglecting that the balance of payments is not based on an equilibrium, but on an "identity" (International Monetary Fund, 2009). In other words, CAB $+\mathrm{CFAB} \equiv 0$ where CAB corresponds to the current account and CFAB to the capital and financial account balance "Alternatively, it could be said that the current account balance is equal to the sum of balances on the capital and financial accounts (with signs reversed, if necessary, depending on the presentation used) including reserve assets" (International Monetary Fund, 2009). Yet, accepting that today's balance-of-payments entries are often derived independently from different sources (with consequent risk of time lags) confirms once again the implicitly underlying single-entry bookkeeping conception and reduces the balance of payments itself to a mere collection of statistical data instead of being a clear-cut T-account of all external transactions. 
INSIGHTS INTO REGIONAL DEVELOPMENT

ISSN 2669-0195 (online) http://jssidoi.org/IRD/

2020 Volume 2 Number 3 (September)

http://doi.org/10.9770/IRD.2020.2.3(1)

\section{The involvement of current account and capital and financial account in countries' external transactions}

Current account and capital and financial account play a role not only in the transactions carried out by countries' residents, but also in the impact of these transactions on the international investment position of countries considered as sets of their residents. The aim of this section is to verify to what extent this involvement is influenced by whether the present system of international payments complies with the principle of double-entry bookkeeping. Carried out by countries' residents, cross-border payments concern the systems of national and of international payments. Both are founded on the use of bank money, hence on the necessary equality, the identity, of credit and debit. Economists all over the world accept this identity, which is nothing other than the principle of double-entry bookkeeping. Within nations, national banking systems function consistently with this principle, while at the international level balances of payments are, at least in theory, assumed to adopt it as a necessary reference. Is this enough? Can double-entry be considered as a guiding principle, as a reference, or as a point of equilibrium that can only be approximated but hardly ever or very seldom reached? We shall argue that the answer to both questions is no. In no way can logical identity be avoided; but neither can it ever become a condition of equilibrium. If, nonetheless, it is not complied with, a disorder ensues, which weighs heavily on countries and their residents. It is an indisputable fact that cross-border transactions take place between the residents of any given country and those of the rest-of-the-world. This is true even in the case of public transactions, for the simple and obvious reason that public institutions as well as the State itself are residents of their own country. Whether public or private, international payments are carried out by banks in compliance with the double-entry bookkeeping rule establishing the necessary correspondence of credits and debits. If a resident $a$ of country A purchases commercial goods or financial assets of a value equal to $x$ units of money A, MA, from a resident $b$ of country $\mathrm{B}$, it is tautological to say that $a$ 's purchases are $b$ 's sales. It is also a truism to claim that the payment of $a$ 's purchases defines the debit of $a$ 's bank account and the equivalent credit of $b$ 's bank account. If nothing more could be said about this payment, we would have to conclude that double-entry is nothing more than the matching of two separate entries in two distinct accounts, each entry being in all respects simple. Reality is far richer: double-entry entails both the debit and the credit of each agent involved in any transaction, national or international. In our example, agent $a$ can pay for its international purchases only if it holds the amount of income required to finance them. Only two possibilities are relevant: either $a$ is the holder of a previously earned income deposited in its bank account, or it obtains it through a sale of claims on the financial market (we leave aside gifts and inheritance, because irrelevant here). In the first case, when $a$ 's bank pays $b$ on behalf of its client, it credits $a$ with $x$ MA, because $a$ gives up $x$ MA of its bank deposits, and immediately debits it with $x$ MA, because of $a$ 's payment in favour of $b$. A bank deposit is a claim on the bank in which it is formed. When $a$ gives up its claim or part of it, the bank cancels a debit and credits $a$ with the amount of money previously deposited. In the second case, assuming that $a$ sells a sum of financial assets equal to $x$ MA and immediately spends the $x$ MA it obtains in order to pay $b$, it is clear that $a$ is at once credited and debited by its bank for an amount of $x$ MA. The logical identity of $a$ 's debit and credit appears in all its clarity it we drop the restrictive assumption introduced in the second case. Indeed, the introduction of a time interval separating $a$ 's sales of financial assets from its commercial purchases from $b$ allows us to dispel the impression that, at least in the second case, the couple credit-debit can be obtained through two distinct, but simultaneous, operations on two different markets. Indeed, if $a$ sells financial claims worth $x$ MA at time $t_{0}$ and purchases $b$ 's goods at time $t_{l}$, the credit-debit identity is verified both at $t_{0}$ and at $t_{l}$. To verify this, one only needs to observe that at the very instant $a$ is credited with $x$ MA because of its financial sale, it is also debited with the same amount following the immediate deposit of $x$ MA in its bank account. As a result of its sale of financial assets, $a$ owns a right on a bank deposit and not a sum of money, of which it has been debited. At the later instant $t_{1}$, when $a$ purchases from $b$, it is likewise credited, because of the cancellation of its bank deposit, and debited, because of the payment of $b$.

The analysis of what happens to $b$ is straightforward, since it is simply the mirror image of what applies to $a$. Credited in money $\mathrm{B}, \mathrm{MB}$, for its commercial sales to $a, b$ is at the same time debited by its bank, where the $y \mathrm{MB}$ (if $x \mathrm{MA}=y \mathrm{MB}$ ) are instantly deposited. Identity credit-debit applies to each single economic agent and to each 


\section{INSIGHTS INTO REGIONAL DEVELOPMENT}

ISSN 2669-0195 (online) http://jssidoi.org/IRD/

2020 Volume 2 Number 3 (September)

http://doi.org/10.9770/IRD.2020.2.3(1)

single transaction. A mere transposition of the principle of double-entry bookkeeping, this identity can also be expressed, as Schmitt did (1975), as the law of the necessary equality between each single agent's sales and purchases. This means that every single transaction on any market is necessarily balanced by an immediate reverse transaction on another market. Let us refer once more to our simplified example. When agent $a$ is a purchaser on the trade market of $b$ 's goods, Schmitt's law states that $a$ is also, at the same time, a seller on the financial market. Bank deposits are financial claims, so that when $a$ gives back to its bank the rights on its bank deposits it is indeed selling an amount of financial assets. Finally, $a$ 's net commercial purchases of $b$ 's real goods are financed by equivalent and simultaneous sales of financial claims. Agent $b$, on the other hand, balances its commercial sales to $a$ with an equivalent purchase of financial assets, claims on the bank where the proceeds of its sales are deposited.

It is thus confirmed that payments between residents, whether of the same country or of different countries, comply with the identity of their debits and credits, each purchase being financed by an equivalent and simultaneous sale. In other words, this means that money intervenes to convey reciprocal exchanges the objects of which are commercial and financial assets. Perfectly in line with Adam Smith's definition of money as the 'great wheel of circulation' (Smith, [1776] 1978), this notion of money as a 'vehicle' is the only one compatible with double-entry bookkeeping. In our example, MA and MB convey the payments between $a$ and $b$; yet, neither MA, nor MB are an object of exchange. What agent $a$ gives in exchange for a sum of goods sold by $b$ is not a sum of MA, nor is it a sum of MB in which MA is transformed. Both MA and MB are vehicular means of payment; through their circular flow $a$ and $b$ exchange commercial goods against financial assets. Does the circular flow of money occur also when countries take over the foreign payments of their residents? This question calls for an analysis of the involvement of countries in the cross-border payments of their residents, State included.

The need to transfer abroad the cross-border payments initially made in national currency by their residents, leads to the direct involvement of their countries. If residents of country A are net importers of commercial goods from the rest-of-the-world, $\mathrm{R}$, it is country A that is a net commercial importer, even though A's imports may not be traced back to any specific importer or exporter. The role of countries, or of their central banks, is to convert the payment in national money of their residents into a payment in foreign currency. In other words, they must convey through the 'international space' the external payments initially carried out in domestic currency. As officially recognized by international institutions such as the IMF and the WB, international transactions carried out by countries must comply with the balance of payments identity between entries in CA and entries in the $\mathrm{CFA}$, the CA being the mirror image of the CFA. The necessary equilibrium between the transactions entered in the CA and those entered in the CFA means that a country's net commercial imports (resp., exports) must be balanced by equivalent net financial exports (resp., imports). Hence, A's net trade surplus is immediately matched by an equivalent deficit of its CFA. This is so because the payment of A's net imports gives rise to an inflow of foreign currencies into country RW, which are immediately invested in A. It is thanks to this investment, corresponding to the purchase by RW of an equal amount of A's financial assets, that A can finance its net commercial purchases from $\mathrm{R}$.

Expressed as the identity between each country's global imports, IM, and its global exports, EX, the balance of payments identity is a logical principle accepted worldwide. If it were duly complied with, it would guarantee the vehicular use of any currency used to carry out international payments. The IM $\equiv$ EX identity establishes on logical grounds the fact that the terms of any international exchange are always and necessarily real goods, either in the form of commercial goods or of financial assets. If the trade balance is in equilibrium, both terms of the exchange are actual goods. If it is not, the difference is an exchange between present goods and future goods, the latter being the object of the financial claims the export of which matches the net import of commercial goods. Being carried out in bank money, international payments taken over by countries are made through debits-credits and credits-debits, which implies that money is never the object of any payment. As in the case of payments analysed from the viewpoint of residents and non-residents, each country entering international exchange is 


\section{INSIGHTS INTO REGIONAL DEVELOPMENT}

ISSN 2669-0195 (online) http://jssidoi.org/IRD/

2020 Volume 2 Number 3 (September)

http://doi.org/10.9770/IRD.2020.2.3(1)

debited-credited or credited-debited anytime it carries out, or is the beneficiary of, a foreign payment. Let us consider the case where country A is paid by R, in MRW, for its sales of part of its domestic output. As soon as A is credited by RW of a sum of MRW it is debited by the same amount: issued by the banks of R, MRW flows immediately back to its point of departure (double-entry bookkeeping requires it), and in exchange for its commercial exports, A is credited with an equivalent claim on RW's banks, that is, with a claim on a bank deposit in $\mathrm{R}$.

As countries carry out the cross-border payments of their residents, it is not surprising that they are subject to the same rules as their residents. They are involved by implication and their payments are the mere transposition at the international level of those carried out by national importers. The use of banknotes is no exception to the law. It is indisputable, in fact, that banknotes are posit certificates of their issuing bank, which clearly shows that even paid in banknotes, commercial exports (imports) are immediately matched by equivalent imports (exports) of financial claims. It is thus confirmed that, between countries, 'each commercial payment is a financial payment of inverse algebraic sign, [and] each financial payment is a zero-sum transaction unless it is founded on a commercial payment of opposite sign' (Schmitt, 2008 [our translation]). As a consequence of the identity IM $\equiv$ $\mathrm{EX}$, money is nothing more than an intermediary, a circular means of payment that never replaces the real terms, commercial and financial, of any international transaction.

Actually, the preceding conclusion must be somewhat qualified, because it describes the logical nature of international payments and not the way the present system works. IMF and WB experts say that '[i]n principle, the current and capital accounts should be mirror images' (International Monetary Fund, 1987). What is emphasized here is the existence of a discrepancy between theory and practice, between the way the system of international payments should work and the way it actually works. In its present form, the balance of payments is a mere collection of statistical data and not a true bookkeeping representation of countries' foreign transactions and payments. We are thus confronted with a number of inconsistencies, such as those denounced by the IMF Working Party in 1987 and concerning the non-zero amount of the world's CA, which indicates the presence of a disorder the consequences of which, countries' over-indebtedness, are disastrous for countries and their residents.

The relevance of the principle of double-entry bookkeeping for the correct analysis of monetary payments, national and international, as well as for the implementation of an improved methodology of the balance of payments is indisputable. Unfortunately, so far economists have failed to apply this principle in its most elaborate form. By erroneously identifying double-entry with simple double-entry (a mere tautology) rather than with double double-entry, each entry being simultaneously a debit-credit or a credit-debit, they have failed to fully recognize the flow nature of money. The balance of payments in its present form is a direct implication of this truncated conception of double-entry, an analytical instrument not entirely fit for purpose and that must be reelaborated according to the true principle of debits-credits and to Schmitt's law of sales-purchases.

\section{The reserve account (including so-called "reserve assets") is the account of a country taken as a whole}

There is no doubt that "country boundaries recognized for political purposes may not always be appropriate for economic purposes" (International Monetary Fund, 1993). More generally, we have already mentioned that the economic (monetary) definition of "country" or "nation" relies on the money unit involved (US Dollar, Euro, Swiss franc, etc.) and the corresponding banking system (the American, European, Swiss, etc.). By way of example, "the United States of America are a single country from an economic point of view, since a common money unit has legal validity within this geographical region. [...] In each country, banks are organized according to a pyramidal scheme while the central bank tops this banking structure" (Schmitt, 1990 [our translation]). Hence, the monetary unit of physical production, which is used in the payment of wages (monetizing new goods/services and determining national income), has a crucial role in defining each country's monetary space. 


\section{INSIGHTS INTO REGIONAL DEVELOPMENT}

ISSN 2669-0195 (online) http://jssidoi.org/IRD/

2020 Volume 2 Number 3 (September)

http://doi.org/10.9770/IRD.2020.2.3(1)

According to the International Monetary Fund (2009), "[i]nternational accounts can be compiled in the domestic currency as well as in another currency. Data in domestic currency are needed because several other macroeconomic and micro data are compiled in domestic currency, except when a foreign currency is used as a legal tender". Therefore, economic data also contained in international accounts like the balance of payments are compiled in a so-called "reference unit of account", which mostly corresponds to the national currency. The sixth edition of the Balance of payments and international investment position manual rightly reminds us of the distinction between "currency of denomination" (corresponding to the national one in which data are expressed) and "currency of settlement" (corresponding to the national and/or foreign currencies used in the payment itself).

Foreign currencies (for instance, used by foreign trading partners and accepted by national ones) play a major role in external trade. Not surprisingly, the balance of payments also records a statistical item called "reserve assets", which "are readily available to and controlled by monetary authorities for meeting balance of payments financing needs, for intervention in exchange markets to affect the currency exchange rate, and for other related purposes (such as maintaining confidence in the currency and the economy, and serving as a basis for foreign borrowing)" (International Monetary Fund, 2009). At the same time, "foreign currency liquidity" represents a broader concept than "reserve assets" or "international reserves", because it "concerns foreign currency resources and drains on such resources of the monetary authorities and the central government [...], relates to the authorities' foreign currency claims on and obligations to residents and nonresidents and [...] encompasses inflows and outflows of foreign currency that result from both on and off -balance-sheet activities of the authorities" (International Monetary Fund, 2013). Regardless of whether "reserve assets" or "foreign currency liquidity" are specifically involved, it remains true that the flows of net foreign currencies modify the International Investment Position (IIP) of countries defined as "sets of their residents".

Let us separate this assertion into two logically distinct parts, of which the first is the more intuitive. In fact, since "the difference between the assets and liabilities is the net position in the IIP and represents either a net claim or a net liability to the rest of the world" (International Monetary Fund 2019, Internet), it goes without saying that net foreign currency outflows (resp., inflows) reduce (resp., increase) the net claims of a country as whole. The second part of the previous statement is equally true, but needs a more articulated explanation. In fact, we have to demonstrate why countries have to be conceived as "whole sets of their residents" instead of the more intuitive formulation of "aggregate or sum of their residents". More precisely, countries or nations are monetarily speaking the "set of their private/public economic subjects (including the State)". Why the term "State" is not synonymous with "nation" or "country" is plain to see, since the public sector is nothing more than a part, a component, of the economy as a whole (which includes also private, financial and non-financial subjects). But, why would it be wrong to claim that countries do not correspond to the simple aggregate of all (private and public) economic subjects? While the concept of "sum" quite simply implies that all economic actors $\left(\mathrm{S}_{1}, \ldots, \mathrm{S}_{\mathrm{n}}\right)$ of the nation are to be taken together:

$$
\text { country }=\Sigma\left(\mathrm{S}_{1}, \ldots, \mathrm{S}_{\mathrm{n}}\right)
$$

a "set" is not limited to their aggregation. If we graphically represent the macroeconomic concept of "country" by means of an ellipse or a circle containing several elements (national private-public residents), the "set" would correspond to the ellipse/circle as a whole (all its components, including its perimeter):

$$
\text { country }=\Sigma\left\{S_{1}, \ldots, S_{n}\right\}
$$

In Aristotle's [5 ${ }^{\text {th }}$ century BC] (2016) Metaphysics, we find a sentence that has often been quoted, and which quite

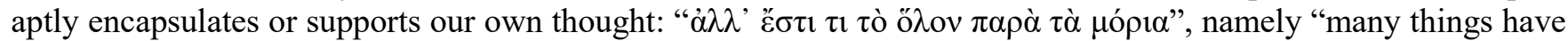
a plurality of parts and are not merely a complete aggregate but instead some kind of a whole beyond its parts". 
INSIGHTS INTO REGIONAL DEVELOPMENT

ISSN 2669-0195 (online) http://jssidoi.org/IRD/

2020 Volume 2 Number 3 (September)

http://doi.org/10.9770/IRD.2020.2.3(1)

Evidently, the concept of "sum of residents" is more immediate, but also relies on purely micro-founded assumptions implying that macroeconomic analysis can be simply derived by considering a sufficiently high number of microeconomic situations, agents etc. As reminded by Cencini (1997), "[i]n the same way as the set is richer than its constitutive elements, the nation is a whole which acquires an existence which is partially autonomous from that of its residents. [...] However, if it is correct to claim that a set cannot be reduced to the sum of its elements, this does not mean that the situation of the set has to be cumulated with that of its elements". For instance, a major logical-analytical proof that the country as a whole is - economically speaking - distinct from the sum of its elements is provided by the essence of international reserves themselves, which are, indeed, owned by countries.

Obviously, trade with the rest of the world is the first source of accumulation of foreign exchange reserves. For example, suppose that country A records a commercial export surplus (+100 MA) with country B, a net commercial importer (-100 MB) and that the exchange rate is of $1 \mathrm{MA}$ to $1 \mathrm{MB}$. What happens as soon as the residents of country B settle their excess purchases of goods and services from A? The payment of B's importers (100 MB, namely the equivalent of $100 \mathrm{MA}$ ) is made possible by the existence of bank deposits owned by the commercial importers in country $\mathrm{B}$. Then, the payment is taken over by the central bank and the corresponding banking system. If MB is a key currency, the latter send this amount (100 MB) to the central bank of country A, which in turn is responsible for crediting the banking deposits of the commercial exporters in country A. The central bank of nation A - after recording the $100 \mathrm{MB}$ received from $\mathrm{B}$ in its international reserves, which confirms that net commercial exports contribute to the accumulation of foreign exchange reserves - has in the meantime issued $100 \mathrm{MA}$ to the benefit of its commercial banks. In fact, there is no doubt that bank customers always make and receive payments in the currency denomination of their bank deposit. This occurs simply because of the banking intermediation of the central bank at the top of each national monetary space. In other words, the central bank of country A monetizes the external profit deriving from A's trade surplus (100 MB) by issuing the countervalue in local currency (100 MA) accruing to commercial exporters.

Hence, international reserves are managed by the central bank on behalf of the country as a whole. More precisely, commercial exporters in country A having been credited with the due amount of 100 MA no longer have any outstanding claims. The fact that "underlying the BPM5 concept of reserves are the notions of "effective control" by the monetary authorities of the assets and the "usability" of the assets by the monetary authorities" (Kester, 2001) does not contradict the logical-analytical conclusion that international reserves do not (monetarily speaking) pertain to any specific resident. Neither do they belong to the State, which might have contributed to their accumulation just by transacting with the rest of the world and which administers them through the central bank. The balance of payments should, therefore, distinguish more unequivocally between the "origin" (residents of the country), "administration" (the central bank) and "economic ownership" (the country as a whole, namely as "set of its residents") of foreign exchange reserves. A similar distinction is precisely necessary, because countries are not just identifiable with the aggregate of all physical/legal persons, defined as their residents.

Issued by a domestic banking system, a country's national currency is an acknowledgment of debt of the whole system. Outside its country of origin, a national currency defines the debt of the country as a whole, independently of the situation of its residents. Consider, for example, the case of a single import of resident $a$ of country A. In order to get rid of its debt, due to its imports, $a$ must credit its bank with an amount of MA sufficient to pay its foreign creditors. Once it has paid for its foreign purchases, $a$ is no longer indebted to anyone. Yet, its country is far from being quits. If A is a key-currency country, the payment of $x$ units of money A, $x$ MA, to RW ends up with the transfer to RW of an amount, equal to $x \mathrm{MA}$, of claims on bank deposits formed in A's banking system. The transfer of financial claims from A to B defines a foreign debt of country A that does not correspond to a debt of any of its importers. This conclusion holds true even if MA, a key-currency, is wrongly considered as a net asset by RW and entered by RW's banking system as the final payment of RW's net exports. Being issued as a spontaneous acknowledgement of debt by A's banking system, the MA entered on the assets 
INSIGHTS INTO REGIONAL DEVELOPMENT

ISSN 2669-0195 (online) http://jssidoi.org/IRD/

2020 Volume 2 Number 3 (September)

http://doi.org/10.9770/IRD.2020.2.3(1)

side of RW's banks defines the acknowledgement of debt of country A itself, which does not match any debt of its resident $a$.

Ad absurdum, if a country were solely represented by the sum of its residents, having settled the above-mentioned commercial transaction the nation as a whole would not record any net commercial surplus (deficit) in the balance of payments. In reality, the external profit of country A deriving from excess trade with the rest of the world represents a claim against country $\mathrm{B}$ and, therefore, a (spontaneous recognition of) debt of the corresponding banking system. The fact that country B still enters a net commercial deficit (-100 MB) even though commercial exporters in nation A have been finally paid constitutes the stringent proof that "a nation can be creditor[/debtor] independently of the creditor[/debtor] position of its residents. [...] once they have been paid by their banks, A's exporters no longer own any credit on their foreign correspondents and yet country A is a net creditor" (Cencini, 2005). Even legally there is no doubt that international reserves do not belong to a central bank or any other specific resident, as art. 3 of the Bundesbank Act reminds us ("[the Deutsche Bundesbank] hold[s] and manage[s] the foreign reserves of the Federal Republic of Germany“ (Deutsche Bundesbank 2013, Internet) or art. 127 para. 2 of the Consolidated version of the Treaty on the functioning of the European Union ("the ESCB [...] hold[s] and manage[s] the official foreign reserves of the Member States" (European Union 2012, Internet)). Even when international reserves are owned by the central bank ("The Bank of Italy owns and manages the country's official reserves in foreign currency and gold" (Banca d'Italia 2019, Internet)), the central bank is acting on behalf of the undifferentiated set of the country's residents. This does not alter the initial claims according to which net foreign currencies' flows modify the IIP and this affects the country as a whole (not any specific private or public individual).

The fact that public (the State) and private institutions as well as individuals are elements of a whole defined as their country is implicitly confirmed by the IMF ("The sectors of an economy are composed of [...] (i) households and individuals who make up a household and (ii) legal and social entities, such as corporations and quasi-corporations (e.g., branches of foreign direct investors), nonprofit institutions, and the government of that economy" (International Monetary Fund, 1993)). The existence of countries as sets of their residents should lead to a new conception of the official reserves account. Re-imagining the role of "reserve assets" would be a necessary step. Today, in fact, as already mentioned, reserve assets appear to be involved merely in a limited number of transactions, mostly carried out by monetary authorities. Besides, - at least, in key-currency countries, whose means of payments are internationally accepted - they appear to have compensatory features rather than being a systematic account recording all transactions modifying the external position of the economy altogether. More precisely, since commercial and financial transactions recorded in the balance of payments pertain to private and public agents (residents) but contribute to modifying the nation's position as a whole, a country's economic account should also be created. This account would represent the flow-version of the already existing International Investment Position (IIP) and, by means of a double-entry bookkeeping approach, would highlight the involvement of the economy as a whole. The official reserves account would mainly deal with foreign reserves (as it already does) and it would represent the account of the country taken as a whole. Closely related to the inflows and outflows of foreign currencies, the reserve account would be directly involved in every current, capital and financial account transaction. Hence, for example, a commercial export would entail an increase in the country's official reserves caused by the positive inflow of a sum of foreign currency. Substantially, the reserve account would mirror the evolution of an important part of the country's IIP and represent the country's external financial position as defined by its net stock of financial assets and liabilities.

The implementation of such reform step would imply a new way of recording cross-border payments, paving the way for the creation of a new international payments system. The balance of payments is, even today, a powerful tool, but in order to display its "true" macroeconomic significance adjustments must be made by reformulating the official reserves account in a money-consistent way. As explained in Part 5, a profound reform is needed so that the balance of payments can be finally transformed into a bookkeeping instrument belonging both to the country 
as a whole (macroeconomic dimension) and its residents (microeconomic dimension). This would also prevent the persistence of imbalances in the current account (Table 2).

Table 2. Current account imbalances at the world level (US Dollars, billions)

\begin{tabular}{|c|c|}
\hline & Current account balance \\
\hline 2010 & +287.08 \\
\hline 2011 & +351.56 \\
\hline 2012 & +406.28 \\
\hline 2013 & +384.30 \\
\hline 2014 & +402.63 \\
\hline 2015 & +242.18 \\
\hline 2016 & +293.37 \\
\hline 2017 & +423.72 \\
\hline
\end{tabular}

Source: own representation on the basis of International Monetary Fund (2020b)

Undoubtedly, the commercial exports of any country are necessarily, and tautologically, the commercial imports of other countries. Yet, this is not so. Global current accounts show the presence of persistent discrepancies between deficits and surpluses ("What can explain these discrepancies? Was the Earth a net importer of goods and services from other planets before 2005 and a net exporter afterwards? [...] The IMF's projection for the next five years is that these discrepancies will decrease (as they have been since 2012) and that the world current account will be negative. Accounting for the magnitude of these errors is difficult and still important to understand the existence of global imbalances around the world" (Federal Reserve Bank of St. Louis, 2016). What makes things worse is that the cumulated capital and financial account should also be equal to zero for the world taken as a whole, but it is not. This is shown (though subject to statistical discrepancies) in Table 3. Although these data are biased by insufficient transparency (at least, for some countries) and by the presence of the "net errors and omissions" item (see Table 4), not a negligible component, the picture is pretty clear: statistical discrepancies are very evident, enduring and - more relevantly - symptomatic of the fragmentary approach to the recording of transactions, whereas they should be registered in a simultaneous and identical-in-value way.

Table 3. Capital and financial account imbalances at the world level (US Dollars, billions)

\begin{tabular}{|c|c|c|c|}
\hline & Capital account balance & $\begin{array}{c}\text { Financial account } \\
\text { balance }\end{array}$ & $\begin{array}{c}\text { Capital and financial } \\
\text { account balance }\end{array}$ \\
\hline 2010 & +74.32 & +31.82 & +106.14 \\
\hline 2011 & +65.19 & +57.31 & +122.50 \\
\hline 2012 & +56.83 & +58.18 & +115.01 \\
\hline 2013 & +69.17 & +277.32 & +346.49 \\
\hline 2014 & +9.39 & +379.50 & +399.89 \\
\hline 2015 & +20.40 & +60.65 & +81.05 \\
\hline 2016 & +19.81 & +47.52 & +67.33 \\
\hline
\end{tabular}

Source: own representation on the basis of International Monetary Fund (2020b)

Undeniably, it is the central bank of each country that ensures payments compensation between private banks giving them a homogenous "form" by means of the currency of the national banking system. By doing so, it also allows for the national monetary process coming full circle and the instantaneous "closure" of the national monetary circuit, which would instead remain "open" if no common monetary denominator were provided to currencies issued by different commercial banks ("Dans un système bancaire, toute monnaie émise par une banque est éligible à la compensation, mécanisme par lequel la monnaie de toute banque peut être librement convertie ou transformée objectivement - dans une opération de change absolu - en monnaie d'une autre banque" 
INSIGHTS INTO REGIONAL DEVELOPMENT

ISSN 2669-0195 (online) http://jssidoi.org/IRD/

2020 Volume 2 Number 3 (September)

http://doi.org/10.9770/IRD.2020.2.3(1)

(Schmitt, 1990)). A similar mechanism is needed for the settlement of cross-border transactions. Since the monetary concept of "nation" corresponds to the set of its private/public economic subjects (including the State itself), it is crucial that the workings of the balance of payments itself should duly reflect it. As briefly presented in the last part of this paper, this mechanism is based on the implementation of double double-entry bookkeeping by central banks, which will act on behalf of countries and of their residents.

\section{Today's system of international payments does not recognize the existence of countries as sets of their residents. A new, conceptually reformed approach has to be developed}

In this last section we consider the main shortcomings of the present conception of international payments and we outline the principles of a reform of the balance of payments complying with the rule of double-entry bookkeeping. We start from the factual observation that nations or countries exist as monetary entities, note that money is still wrongly identified with a positive asset, analyse the implications of this erroneous notion of money, and end by advocating the institution of a National Bureau responsible for carrying out the external payments of the country's residents according to the law of debit-credit and credit-debit.

The totality of any country's external transactions is carried out by its residents, State included. The country itself, as the set of its residents, is no autonomous economic agent. It neither imports or exports either commercial goods or financial assets. We would therefore infer, too hastily, that a country is nothing more than the mirror image of its residents. While it is true that countries are involved by implication, since the cross-border transactions of their residents require their monetary intermediation, it is also true that the end result of these transactions concerns the country as a whole as well as its individual residents. Hence, although net exports cannot be attributed to any particular exporter or to any particular importer, they define a net gain for the country itself. Transferred to the country's official reserves, this gain is that of the undifferentiated set of residents, of the country as a whole. Ultimately, it is monetary sovereignty that determines the economic existence of countries as such. Insofar as countries maintain their national currencies, they exist as distinct economic entities. At the same time, countries act as monetary intermediaries in the foreign payments of their residents. For these two reasons, they should be endowed with a mechanism accounting for their commercial and financial situation (the balance of payments) and allowing for their payments to be carried out in compliance with double-entry bookkeeping.

The net asset definition of money is unfortunately still widespread and a major obstacle to the understanding of its vehicular use, the only one compatible with double-entry. If money were not substantially distinct from real goods, economics would not even exist for lack of a numerical standard. Even issued by banks, money would be unable to relate to physical goods and could therefore not make them commensurable. The determination of numerical prices would remain mysterious, elusive, and the explanation of the purchasing power of money metaphysical, surreal. To claim that banks can issue money already endowed with a positive purchasing power is pure nonsense. Fortunately, double-entry comes to our rescue and guides us toward a modern conception of money. The necessary equality of debits and credits is the guiding principle, our lodestar. Money is spontaneously issued by banks, lent to the economy, and recovered in payments entered by banks in conformity with that equality. Far from being the result of a miraculous creation of a positive asset out of nothing, money is createddestroyed on both purchaser and seller and flows immediately back to its point of origin. Instead of financing monetary payments, it conveys them through its circular flow. As a means of payment (as distinct from the real objects involved in the payment), money is a numerical flow allowing for the exchange of real goods and financial assets.

Nationally, money is associated to production via the payment of productive services and plays the double role of unit of account and of numerical means of payment. Internationally, the intervention of money is limited to its vehicular role. As our main concern here is the balance of payments, let us consider the monetary aspect of international transactions. The question to be answered is whether or not payments between countries 


\section{INSIGHTS INTO REGIONAL DEVELOPMENT}

ISSN 2669-0195 (online) http://jssidoi.org/IRD/

2020 Volume 2 Number 3 (September)

http://doi.org/10.9770/IRD.2020.2.3(1)

acknowledge the flow nature of money. If they do, the present system of international payments is already an orderly one; if they do not, it must be reformed. The answer is not an easy one, because the credit-debit (resp. debit-credit) pair is in fact a logical identity, and identities will prevail whether they are complied with or not. Suppose, as is the case today, that the structure of the system of payments is inadequate: money will necessarily still obey the logic of those accounting identities. It is therefore already the case today that the monetary payment of a country's net commercial imports transfers to the exporting country an amount of financial claims (deposit certificates) and not a sum of money. If this fact were overtly recognized and if cross-border payments were entered accordingly in the respective balance sheets, everything would be perfect. However, this is not yet the case, which implies that, even though money paid by, say, country A flows back to A's banking system at once, it remains also recorded on the assets side of RW's banks. Submitted to what Jacques Rueff called a duplication, money A, its duplicate, remains available in $\mathrm{R}$, where it defines a pathological capital of an inflationary nature (Schmitt, 1984).

A negative consequence of the lack of an orderly structure of international payments is the fact that, although money 'moves', of necessity in an instantaneous circular flow, countries have to purchase at a cost the vehicular money that is not explicitly provided by the system. Now, while it is true that when international payments are reciprocal these costs cancel each other out, there is an important case where this equalisation does not occur: the payment of interest on external debts. As clearly demonstrated by Schmitt (2004; 2012), interests are a spontaneous debt the payment of which, defined by the IMF and the World Bank as a unrequited transfer, is uncompensated. The country carrying it out transfers unilaterally part of its domestic resources without obtaining anything in exchange except the cancellation of its interest on debt. If the payment of interest were part of a reciprocal exchange between debtor and creditor countries, it would imply the circular use of a vehicular money and its cost for the debtor country would correspond to that of its internal resources only. The payment being unilateral, a monetary cost is added and the total cost for the debtor country doubles: on top of the loss of part of its national product, it has to pay for its 'monetary transfer' abroad. As absurd as it may seem, indebted countries pay twice their interests on debt $t^{\dagger}$. One payment is microeconomic in nature and rests on the indebted country's residents. This payment is entirely justified. The second, pathological payment rests on the country taken as a whole, the set of its residents. This payment is macroeconomic and it is due to an anomaly of the present system of international payments, which does not provide countries with a mechanism guaranteeing the circular use of a vehicular money. Indebted countries have to purchase, at a cost, the vehicular money required to convey abroad the object (national resources) of their payment, which should be provided cost free by the system of international payments.

The system of international payments in its current form is flawed because it is at odds with the flow nature of money and with the double-entry principle. This is also true of the balance of payments. Being a mere collection of separate statistical data, the balance of payments hardly complies with the bookkeeping identity on which it should be founded. Billion-high net errors and omissions on the national as well as global level are an enduring consequence (Table 4). The perfect correspondence between CA and CFA (with a reverse sign) cannot be the unstable and highly unlikely result of an equilibrium between separate transactions. It is only by entering each single transaction as a debit-credit or a credit-debit that the balance of payments can be considered as a bookkeeping representation of the foreign exchanges, both commercial and financial, of a country. The principle is simple. Like its residents, a country can finance its purchases only through equivalent and simultaneous sales, its imports through its exports. This does not at all mean that each country does or should necessarily balance its commercial imports with equivalent commercial exports. A country can perfectly well run a trade deficit on

\footnotetext{
$\dagger$ The same has been argued by Beretta $(2012 ; 2017)$ with specific regard to historical cases of war reparation payments, which are typically unilateral and have to be provided in internationally accepted means of payments.

$¥$ In the appendix the authors also provide a numerical insight into the balances of payments of countries belonging to the Group of Seven (G7) (Table 5).
} 
condition that it bankrolls it through an equal financial surplus, that is, through a sale of financial claims. The reciprocity of exchanges subsumes both the commercial and the financial markets, any net commercial purchase being covered by a net sale of claims on part of the country's future output. It is not the trade balance of any single country that must be in equilibrium, but its monetary balance, its overall inflows and outflows of foreign currencies. The identity of IM and EX corresponds to the identity between each country's global sales and purchases. Its corollary is the necessary equilibrium of their monetary balances, the vehicular use of the currency used to convey their reciprocal payments.

Table 4. Net errors and omissions in the balance of payments of the world (US Dollars, billions)

\begin{tabular}{|c|c|}
\hline & Net errors and omissions \\
\hline 2010 & -329.58 \\
\hline 2011 & -359.44 \\
\hline 2012 & -404.93 \\
\hline 2013 & -176.15 \\
\hline 2014 & -32.53 \\
\hline 2015 & -201.92 \\
\hline 2016 & -265.66 \\
\hline 2017 & -227.86 \\
\hline
\end{tabular}

Source: own represenation on the basis of International Monetary Fund (2020b)

In practice, the reform needed to transform the balance of payments into a bookkeeping account of the external transactions of countries consists in creating, in each country, a national Bureau responsible for all the payments by and in favour of the country's residents. The Bureau must be conceived as a 'dual' institution, Janus-faced as it were: one face, its internal department, turned toward the country's domestic economy, and the other face, its external department, turned toward the rest-of-the-world. In this new scenario, each payment request made by a resident in favour of a non-resident is first submitted to the country's national Bureau, which represents the country as a whole. Using the country's domestic currency, each payment initiated by the country's residents is carried out as a double double-entry procedure. Thus, for example, importers are credited-debited by their banks: their purchases, which imply a debit, are matched by equivalent sales of financial claims (deposit certificates or securities), for the amount with which they will be credited. At the same time, the Bureau's internal department is credited by the sum of national currency spent by importers and debited for an equal amount to the benefit of its external department. Responsible for payments to the rest-of-the-world for their exports, the external department will first purchase financial claims from its domestic economy and then sell them abroad in order to finance its external payment on behalf of country's importers. Every inflow of national or foreign currencies to each department of the Bureau will thus be balanced by equivalent outflows. In the end, currencies will be used as a means to convey payments, and real goods, present and future, will be the only content or object of these payments.

The analytical description above encapsulates the gist of the reform advocated by Bernard Schmitt (2014). However simplified, it does show how any country on its own could reform its mechanism of external payments to avoid falling prey to the pathologies affecting the present non-system of international payments. The principles of the reform derive directly from double-entry bookkeeping and imply a radical change in the way balances of payments are constructed. This is not to say that balances of payments must be completely overhauled. On the contrary, all the rigorous work done by international experts to produce a detailed account of the various transactions involved can be preserved. What must be changed is the way entries are recorded. Every transaction must be entered twice, once as a credit (debit) and once as a debit (credit). This is the essence of the radical 
INSIGHTS INTO REGIONAL DEVELOPMENT

ISSN 2669-0195 (online) http://jssidoi.org/IRD/

2020 Volume 2 Number 3 (September)

http://doi.org/10.9770/IRD.2020.2.3(1)

change necessary to turn the balance of payments from a statistical collection of data into an instrument delivering a clear picture of a country's commercial and financial relationships with the rest-of-the-world.

\section{Conclusions}

A country's balance of payments accounts for its international commercial and financial transactions with the rest of the world. Its significance is not only due to its far-reaching history, since data on goods, services, and financial claims have been published, quite systematically, from the $19^{\text {th }}$ century onwards (see Thirlwall and Gibson, 1992), but also to the underlying double-entry bookkeeping mechanisms. Today, despite being still a powerful tool indicating the external (flow) position of a country towards the rest of the world, it lacks an approach structurally based on double-entry bookkeeping. Otherwise stated, the fact that commercial and financial registrations are recorded separately from each other exposes the balance of payments to billion-high inaccuracies. By doing so, the double-entry bookkeeping logic (which necessarily implies the identical balance between current account and capital and financial account) is openly neglected, turning the balance of payments into a mere statistical instrument.

The paper is a plea for a substantial, conceptual reform which would ultimately implement the double-entry bookkeeping already recognized to be a pillar of the balance of payments itself. This would also erase statistical discrepancies, which are still a serious bias in today's balances of payments. At the same time, the proposed reform would allow for:

- a renovated, reconditioned balance of payments, designed to account for any commercial and financial transactions between residents of the world and their impact on the residents' countries;

- a reformulated version of official reserves as the account of the country itself;

- a truly unbiased account of all international commercial and financial transactions.

The reform proposal outlined here would not be in any way "invasive". Despite introducing major changes in terms of systematicity, countries would be able to adopt and implement it relatively easily. They would benefit quite simply by the assurance that any commercial/financial transaction would not be compensated ex post, but take place bilaterally, as appropriate, and simultaneously. This would also drastically simplify the recording process, now complicated by valuation and time issues (leading in turn to massive, cumulative inaccuracies between the balances of payments of trading countries). A win-win solution, therefore, while times are ripe for embracing a conceptually macroeconomic approach truly in line with double-entry bookkeeping, that is, with the fundamental principles of the balance of payments. 
INSIGHTS INTO REGIONAL DEVELOPMENT

ISSN 2669-0195 (online) http://jssidoi.org/IRD/ 2020 Volume 2 Number 3 (September)

http://doi.org/10.9770/IRD.2020.2.3(1)

\section{Numerical appendix}

Table 5. The balances of payments of countries belonging to the Group of Seven (G7) (US Dollars, billions)

\begin{tabular}{|c|c|c|c|c|c|}
\hline & Years & $\begin{array}{c}\text { Current account } \\
\text { balance }\end{array}$ & $\begin{array}{c}\text { Capital account } \\
\text { balance }\end{array}$ & $\begin{array}{c}\text { Financial } \\
\text { account } \\
\text { balance }\end{array}$ & $\begin{array}{l}\text { Net errors and } \\
\text { omissions }\end{array}$ \\
\hline \multirow[t]{2}{*}{ Canada } & 2007 & +11.05 & -0.27 & +13.37 & +2.59 \\
\hline & 2018 & -45.32 & -0.06 & -36.63 & +8.75 \\
\hline \multirow[t]{2}{*}{ France } & 2007 & -8.72 & +3.39 & +2.66 & +7.99 \\
\hline & 2018 & -19.01 & +2.44 & -34.35 & -17.76 \\
\hline \multirow[t]{2}{*}{ Germany } & 2007 & +235.78 & -2.32 & +253.35 & +19.89 \\
\hline & 2018 & +289.90 & +2.32 & +270.80 & -21.42 \\
\hline \multirow[t]{2}{*}{ Italy } & 2007 & -30.52 & +2.55 & -29.37 & -1.39 \\
\hline & 2018 & +50.56 & -0.74 & +34.69 & -15.13 \\
\hline \multirow[t]{2}{*}{ Japan } & 2007 & +211.74 & -4.03 & +233.81 & +16.11 \\
\hline & 2018 & +174.72 & -1.94 & +181.85 & +9.08 \\
\hline \multirow[t]{2}{*}{ United Kingdom } & 2007 & -103.09 & -0.30 & -127.58 & -24.19 \\
\hline & 2018 & -123.11 & -4.24 & -101.36 & +25.99 \\
\hline \multirow[t]{2}{*}{ United States } & 2007 & -711.03 & +0.38 & -632.85 & +77.80 \\
\hline & 2018 & -490.99 & +3.24 & -445.46 & +42.30 \\
\hline
\end{tabular}

Source: own representation on the basis of International Monetary Fund (2020a)

\section{References}

Aristotle 2006 [5 $5^{\text {th }}$ century BC]. Metaphysics. Lawrence: Published by Digireads.com.

Balance of payments and international investment position manual - sixth edition (BPM6). 2009. Washington, D.C.: Published by International Monetary Fund.

Balance of payments and International Investment Position statistics (BOP/IIP). 2019. Retrieved from http://data.imf.org/?sk=7A51304B6426-40C0-83DD-CA473CA1FD52.

Balance of payments manual - fifth edition. 1993. Washington, D.C.: Published by International Monetary Fund.

Banca d'Italia 2019. Foreign currency and gold reserves, investment portfolio and risk management. Retrieved from http://www.bancaditalia.it/compiti/riserve-portafoglio-rischi/index.html?com.dotmarketing.htmlpage.language=1.

Beretta, E. 2012. The economics of external debt: a Damocles' Sword hanging over the Emergent and the Virtuous (Germany), Banks and bank systems, 7(2): 79-86.

Between nations, the interest multiplier is equal to 2, 2004. in: Research Laboratory in Monetary Economics (Ed.). Quaderno di ricerca no. 12, Lugano-Vezia: Research Laboratory in Monetary Economics, 1-54.

Brésil en 2008. Les médias donnent une image fortement lénifiante de son passif financier envers le reste du monde. Fribourg: Published by Université de Fribourg. 


\section{INSIGHTS INTO REGIONAL DEVELOPMENT}

ISSN 2669-0195 (online) http://jssidoi.org/IRD/ 2020 Volume 2 Number 3 (September)

http://doi.org/10.9770/IRD.2020.2.3(1)

Cencini, A. 1997. Monetary theory, national and international. London and New York: Published by Routledge Frontiers of Political Economy.

Citraro, M. 2004. World discrepancies in the balance of payments - PhD Dissertation. Lugano: Published by Università della Svizzera italiana.

Deutsche Bundesbank 2013. Bundesbank Act. $\quad$ Retrieved http://www.bundesbank.de/resource/blob/618304/6d6986cbc43dff11cf78d56b2c29502b/mL/bundesbank-act-data.pdf.

European Union 2012. Consolidated version of the Treaty on the functioning of the European Union. Retrieved from http://eurlex.europa.eu/legal-content/EN/TXT/PDF/?uri=CELEX:12012E/TXT\&from=IT.

Federal Reserve Bank of St. Louis 2016. Global current account surplus: is there trade with other planets?. Retrieved from http://www.stlouisfed.org/on-the-economy/2016/february/global-current-account-surplus-trade-other-planets.

From reparations to (net) interest payments on external debt. 2017. Same script, different cast, in: Bailly, J.-L; \& Cencini, A.; \& Rossi, S. (Eds.): Quantum Macroeconomics. The legacy of Bernard Schmitt, London and New York: Routledge, 105-121.

International Monetary Fund 1987. Report on the world current account discrepancy. Washington, D.C.: Published by International Monetary Fund.

International reserves and foreign currency liquidity. Guidelines for a data template. 2013. Washington, D.C.: Published by International Monetary Fund.

Kester, A. Y. 2001. International reserves and foreign currency liquidity: guidelines for a data template. Washington, D.C.: Published by International Monetary Fund.

Krugman, R. P.; \& Obstfeld, M. 1997. International economics: theory and policy - fourth edition. Boston: Published by Addison-Wesley Longman, Inc.

L'Écu et les souverainetés nationales en Europe. Paris: Published by Dunod. 1990

Les pays au régime de FMI. Albeuve: Published by Castella. 1984.

Macroeconomic foundations of macroeconomics. 2005. London and New York: Published by Routledge Frontiers of Political Economy.

Meade, E. J. 1970. The balance of payments. London, New York and Toronto: Published by Oxford University Press.

Organisation for Economic Co-operation and Development 2010. International reserve assets. Retrieved from http://stats.oecd.org/glossary/detail.asp?ID=2319.

Pilkington, M. 2007. A macroeconomic analysis of the role of trans-national corporations in a monetary theory of production, in: Esen, O.; \& Ogus Binatly, A. (Eds.). Proceedings of the SUNY Cortland Conference on globalization and its discontents, Izmir: Izmir University of Economics, 148-173.

Schmitt, B. 1975. Théorie unitaire de la monnaie, nationale et internationale. Albeuve: Published by Castella.

Smith, A. 1978 [1776]. The wealth of nations. Harmondsworth: Published by Pelican Classics.

Sovereign debt and interest payments, 2012. in: Gnos, C.; \& Rossi, S. (Eds.). Modern monetary macroeconomics, Cheltenham: Edward Elgar Publishing, 239-260.

Stern, R. M. 1973. The balance of payments. Theory and economic policy. London and Basingstoke: Published by Macmillan.

Teunissen, J. J. 1987. The international monetary crunch: crisis or scandal?, Alternatives - Social transformation and human governance, 1 (3): 359-395. 
INSIGHTS INTO REGIONAL DEVELOPMENT

ISSN 2669-0195 (online) http://jssidoi.org/IRD/ 2020 Volume 2 Number 3 (September) http://doi.org/10.9770/IRD.2020.2.3(1)

The balance of payments manual - fifth edition. 1997. Washington, D.C.: Published by International Monetary Fund.

The formation of sovereign debt. Diagnosis and remedy. 2014. Retrieved from http://ssrn.com/abstract=2513679.

The sovereign debt crisis. 2017. in: Bailly, J.-L; \& Cencini, A.; \& Rossi, S. (Eds.). Quantum Macroeconomics. The legacy of Bernard Schmitt, London and New York: Routledge, 144-157.

Thirlwall, A. P.; \& Gibson, H. D. 1992. A history of the UK balance of payments, in Thirlwall, A.P.; \& Gibson, H.D. (Eds.). Balance-ofpayments theory and the United Kingdom experience, London: Palgrave Macmillan, 219-271.

World and regional tables: balance of payments and International Investment Position by indicator (BPM6). 2020a. Retrieved from http://data.imf.org/regular.aspx?key=60961513.

World and regional tables: global discrepancies in balance of payments statistics. 2020b. Retrieved from http://data.imf.org/regular.aspx?key=60947556.

\section{Acknowledgements}

This research was partly supported by the project, which has received funding from the European Union's Horizon 2020 research and innovation programme European Research Council (ERC) under the European Union's Horizon 2020 research and innovation programme Marie Sklodowska-Curie Research and Innovation Staff Exchanges ES H2020-MSCA-RISE-2014 CLUSDEVMED (2015-2019) Grant Agreement Number 645730730. The authors would also like to express their sincerest gratitude to Manuela Tvaronavičiene for the great opportunity and to Simona Cain for her wise and careful editing work. The paper has been also presented in the Joint Banco de Portugal, Irving Fisher Committee on Central Bank Statistics and European Central Bank Conference on "Bridging measurement challenges and analytical needs of external statistics: evolution or revolution?” (Banco de Portugal, February 17- 18, 2020). A shorter and, at some points, modified version of this paper with the title "Double-entry bookkeeping and the balance of payments: the need for a substantial, conceptual reform" will also appear in the IFC Bulletin published by the Irving Fisher Committee on Central Bank Statistics (IFC). The authors also thank the conference organizers for their interest in their research.
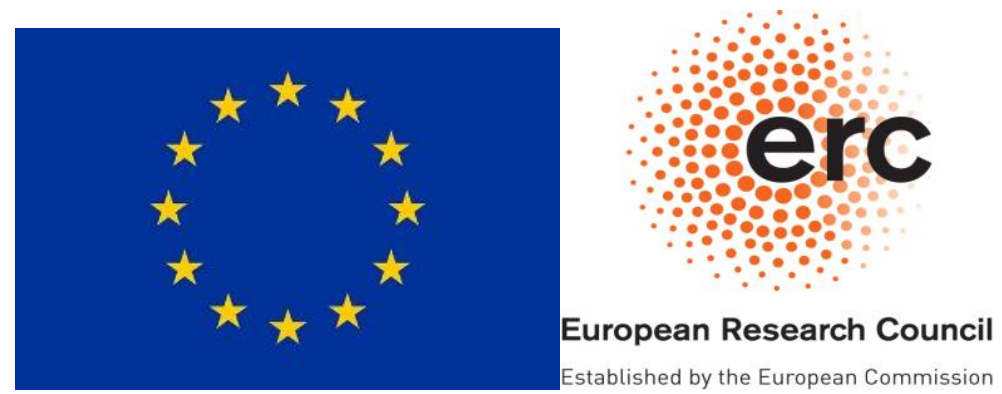
INSIGHTS INTO REGIONAL DEVELOPMENT

ISSN 2669-0195 (online) http://jssidoi.org/IRD/ 2020 Volume 2 Number 3 (September) http://doi.org/10.9770/IRD.2020.2.3(1)

Edoardo BERETTA is the Director of examinations of the Faculty of Economics, a member of the Scientific Directorate and the Program Manager of the Swiss part of the Double Degree Master in Economics and International Policies (MEPIN) at the Università della Svizzera italiana (USI) in Lugano (Switzerland) where he also teaches international macroeconomics to Master's students. He has also been an Adjunct Professor at the Department of Economics and Finance of Franklin University Switzerland (FUS) in Lugano-Sorengo (Switzerland). Edoardo Beretta holds two PhD Degrees in Economics and his research focus lies on international monetary macroeconomics. In this specific regard, he has analyzed selected aspects like the German (external) war debt problem, the ongoing debate on the international monetary order as well as several reform proposals of the international payments system.

ORCHID ID: https://orcid.org/0000-0002-2196-455X

Alvaro CENCINI is Professor Emeritus of the Faculty of Economics at the Università della Svizzera italiana (USI) in Lugano (Switzerland) where he has also hold the Chair of Monetary Economics. He is also the Co-Director of the Research Laboratory in Monetary Economics (REMLab) at the Centre for Banking Studies in Lugano and an external member of the Centre d'études monétaires et financières of the University of Burgundy in Dijon (France). He has a D.phil degree of the University of Fribourg (Switzerland) and a Ph.D. degree of the London School of Economics in London (United Kingdom). Among his main publications are: Time and the Macroeconomic Analysis of Income (Pinter Publishers and St. Martin's Press; 1984, Bloomsbury, 2013), Money, Income and Time (Pinter Publishers, 1988; Bloomsbury 2013), External Debt Servicing. A Vicious Circle (Pinter Publishers, 1991, co-authored with Bernard Schmitt), Monetary Theory, National and International (Routledge, 1995, reprinted 1997), Inflation and Unemployment (Routledge 1996, co-edited with Mauro Baranzini), Monetary Macroeconomics. A New Approach (Routledge, 2001, reprinted 2014), Macroeconomic Foundations of Macroeconomics (Routledge 2005, reprinted 2007), Economic and Financial Crisis (Palgrave/Macmillan 2015, co-authored with Sergio Rossi). He is also the author of several contributions to books and peer-reviewed journals.

ORCHID ID: https://orcid.org/0000-0002-5117-5703

Register for an ORCID ID:

https://orcid.org/register

Copyright (C) 2020 by author(s) and VsI Entrepreneurship and Sustainability Center

This work is licensed under the Creative Commons Attribution International License (CC BY).

http://creativecommons.org/licenses/by/4.0/

(c) (7) Open Access 